\title{
Nexus of Terrorism and Tourism:Empirical evidence from South Asian Countries
}

\author{
Kumail, Tafazal \\ College of Tourism and Service Management, Nankai University, Tianjin, China \\ Ali, Wajahat \\ Department of Economics, Sarhad University of Science and IT Peshawar, KPK, \\ Pakistan \\ Sadiq, Farah \\ Department of Tourism Management, Guangxi University, Nanning, China \\ Khan, Asif \\ Department of Tourism and Hotel Management, Zhejiang University, Hangzhou, \\ China
}

\begin{abstract}
Purpose: To investigate the deleterious role ofterrorism towards tourism, this study analyzed time series data over the period 1980-2016 for South Asian countries including Pakistan, India and Bangladesh.
\end{abstract}

Design/methodology/approach: The study adopted the Autoregressive Distributed Lagged (ARDL) model to investigate the short and long-run estimates simultaneously. The study further applied Granger causality to find out the direction ofcausalities.

Findings: Utilizing the ARDL model, the result indicates that there is strong negative short and long-run relationship between terrorism and tourism in Pakistan, India and Bangladesh. The unidirectional causalities from terrorism, per capita GDP, and terrorism intensity towards tourist's receipts have their implication for the country in terms oftourism development.

Research limitations/implications: The fact that the number of reviews has been used as a proxy is a limitation and adds a provisional character to our results and encourages the replication of our analysis with data on the effective occupation of the accommodation, to which we did not have access to in our case. Similarly, ifpossible, other smaller Latin American cities could be studied.

Research implications: In the perspective of policy implementation, the govemment of Pakistan, India and Bangladesh must take quick actions to control terrorism since it is destructive to the tourism industry as well as in light of its negative effect on economic development of a country. Moreover, the govemment should expand the business and employment opportunities not just in light of the fact that unemployment is harmful to economic growth yet additionally to spare the economy from terrorism as unemployed people can easily become the puppets of terrorist groups by paying them and to feed their families.

Originality/value: This study utilized time series data over a period 1980-2016 for South Asian countries (Pakistan, India and Bangladesh) to investigate the deleterious role ofterrorism towards tourism.

Keywords: Tourism, Tourism, SouthAsian countries, ARDL

\footnotetext{
${ }^{1}$ Department of Economics, Sarhad University of Science and IT Peshawar, Peshawar, North-West Frontier 26000- Pakistan. https://orcid.org/0000-0003-2267-3786

${ }^{2}$ Nankai University - College of Tourism and Service Management Tianjin - Tianjin, China. https://orcid.org/0000-0003-2267-3786

${ }^{3}$ Guangxi University - Department of Tourism Management- Nanning, Guangxi, China. https://orcid.org/0000-0002-1365-0235

${ }^{4}$ Zhejiang University - Tourism and Hotel Management Hangzhou, Zhejiang - China.

(C)This article is published under the Creative Commons Attribution (CC BY 4.0) license. Anyone may reproduce, distribute, translate and create derivative works of this article (for both commercial and non-commercial purposes), subject to full attribution to the original publication and authors. The full terms of this license may be seen at http://creativecommons.org/licences/by/4.0/legalcode
} 


\section{Introduction}

The Tourism is considered a vital measure for improvements and development such as enhancement in employment, income, economic growth, and foreign exchanges. In 2017 the contribution of travel and tourism to economic growth was USD 2,570.1bn which was 3.2\% of total GDP (WTTC, 2018). According to the world travel and tourism council report the direct contribution of travel and tourism in economic growth is expected to increase by $3.8 \%$ per year which is USD3, 890.0bn by 2028 (WTTC, 2018). For many developing countries international tourist to a country or visitors export is a key element of the direct contribution in travel and tourism industry. In 2017, the world generated USD1, 494.2bn in exports of visitor and this amount is increased by $3.9 \%$ in 2018 , which is expected to attract $1,395,660,000$ international tourist arrivals.

Tourism is professed as one of the sources to finance economic growth via attracting foreign exchange. On the other hand, terrorism is considered as cancer for the growth and development of nations as it leaves the country in a state of turmoil in every aspect. Therefore, people must learn how to deal with the changes that this new global terrorist environment has brought to the tourism industry (Veréb et al., 2018) and finding a way to deal with the disruption in tourist flow after a terrorist incident is also critical (Cohen \& Cohen, 2012). There is an irrefutable relationship between terrorism activities and tourism as the terrorist's hot targets are the tourism spots to cause more economic and social disturbance. Continuously, terrorism can be traced to the present day. International terrorism grew rapidly in the late 1960s and early 1970s. After a brief pause in the activity, the 1980s started with terrorist violence and by the end of the decade terrorism became commonly (D'Amore \& Anuza 1986; Richter \& Waugh, 1986). Compared to the first half of the 90s, relatively very few terrorists' incidents have been recorded; however their nature and severity are not easily compared to previous years, as indicated by the US department of state, terrorism's overall threat is very serious, 'the risk of terrorist use of massive destruction materials is an increasing concern. There are many external effects on the tourism industry and on tourist flow and many of them have some major effects such as natural and human disasters. However, the potential risk of terrorism causes a greater reaction. Therefore, terrorism tarnishes the positive image of tourism destination and also threatens its entire tourism business. Hence, tourism is particularly disturbing when continued terrorists attacks affect the image of tourist spots and when terrorist organizations target specifically the tourism industry. Safety is obviously one of the main concerns of tourists and a basic human need. Therefore, it will affect the overall human behavior, especially the behavior of consumers (Isaac \& Velden, 2018). Nowadays, when tourists have to choose their travel destination, safety has become one of their main concerns (World Tourism Organization, 2018).

Numerous studies have been conducted on tourism and terrorist activities. Some of them analyzed the linkage between tourism and economic growth and found a strong positive relationship between these variables Hye (2012), Risso, Barquet et al. (2010), Gunduz* and Hatemi-J (2005). On the other hand, several studies have been conducted to explore the relationship between terrorism and tourism activities and found that there is a significantly negative impact of terrorism on tourism Seddighi, Nuttall et al. (2001), Chen and Noriega (2004), Floyd, Gibson et al. (2004), Kingsbury and Brunn (2004). Table 1 shows the competitive position of Pakistan, India and Bangladesh along with other South Asian countries.

Table 1

Competitive position of Pakistan in tourism

\begin{tabular}{|c|c|c|c|c|c|c|c|c|}
\hline \multirow[b]{3}{*}{ Destinations } & \multirow[b]{3}{*}{ Series } & \multicolumn{4}{|c|}{ International tourist arrivals } & \multicolumn{3}{|c|}{ International tourist receipts } \\
\hline & & \multicolumn{2}{|c|}{$(1000)$} & \multirow{2}{*}{$\begin{array}{r}\text { Change (\%) } \\
16 * / 15\end{array}$} & \multirow{2}{*}{$\begin{array}{c}\text { Share (\%) } \\
2016^{*}\end{array}$} & \multicolumn{2}{|c|}{ (US\$ millions) } & \multirow{2}{*}{$\begin{array}{c}\text { Share }(\%) \\
2016^{*}\end{array}$} \\
\hline & & 2015 & 2016 & & & 2015 & 2016* & \\
\hline South Asia & & 23446 & 25273 & 7.8 & 8.2 & 31554 & 33847 & 9.2 \\
\hline Afghanistan & &.. &.. &.. &.. & 82 & 49 & 0.0 \\
\hline Bangladesh & TF & .. & .. & .. & .. & 150 & 175 & 0.0 \\
\hline Bhutan & TF & 155 & 210 & 35.1 & 0.1 & 94 & 90 & 0.0 \\
\hline India & TF & 13284 & 14569 & 9.7 & 4.7 & 21013 & 22427 & 6.1 \\
\hline Iran & VF & 5237 & 4942 & -5.6 & 1.6 & 3868 &.. &.. \\
\hline Maldives & TF & 1234 & 1286 & 4.2 & 0.4 & 2569 & 2730 & 0.7 \\
\hline Nepal & TF & 539 & 753 & 39.7 & 0.2 & 481 & 446 & 0.1 \\
\hline Pakistan & TF &.. &.. &.. &.. & 317 & 323 & 0.1 \\
\hline Sri Lanka & TF & 1798 & 2051 & 14 & 0.7 & 2981 & 3518 & 1.0 \\
\hline
\end{tabular}

Source: World Tourism Organization (UNWTO, 2017)

\begin{tabular}{ll}
\multicolumn{2}{l}{ Series of International tourist arrivals and departures: } \\
\hline TF & International tourist arrivals at frontiers (overnight visitors, i.e. excluding same-day visitors) \\
VF & International visitors arrivals at frontiers (tourists and same-day visitors) \\
$*$ & Provisional figure or data \\
.. & Figure or data not (yet) available
\end{tabular}

The question is what is the relationship between tourism and terrorism? This study investigates this question by utilizing time series data over a period of 1980-2016 in case of Pakistan, India and Bangladesh. The current study is different from previous studies as some of the previous studies focused on the number of injuries as a proxy for terrorism while others emphasized on the number of fatalities to show the effect of terrorism on economic growth, however, based on Global Terrorism Index, this study covers the overall data regarding terrorism in the shape of an index of terrorism with proper weight to number of injuries (0.5), number of fatalities (x3), number of incidents (x1), and property damage (2). Moreover, this study is different from other studies regarding the intensity of terrorist activities by including a dummy variable measuring the terrorism intensity in the years 2008-2016. 


\section{Literature review}

Regardless of the economic strength of tourism, terrorism can be one of the major threats to tourism industry. It is perceived that terrorism has a negative impact on economic growth as well as on society, particularly on tourism industry. Ender and Sandler and Parise (1992) presented a theoretical framework to link terrorism activities to tourism demand. They argued that tourists being rational consumers will apportion their budget to different goods and services, including tourist trips. They calculated all this budget allocation under two-stage budgeting decision as tourists are consumers and they have two broad categories of commodities: tourism related activities and other economic activities. They argued that the outlay of money, risk factors and time value are among the main sources of alterations in prices of tourist's related activities. Therefore, any unpleasant change that increases the risk in travelling such as terrorism related activities in any country will lead to an increase in the relative prices for consumers (tourists). This increase in terrorist's activities in one country where tourists are perceived to be at higher risk would result decreasing the tourist's activities following substitution effect (more of less-risky activities and vice versa). They further argued that aggregate demand ratio for tourism related activities by these consumers who are also tourists is independent of income, but is actually dependent upon factors that can affect the relative prices for travelling to various countries, main factors of these are threat of terrorism and other consideration in determining relative prices. Based on this discussion, it is very much clear that terrorism and tourism related activities are linked with each other.

Numerous studies have found that there is a strong negative impact of terrorism on tourism worldwide. In their book, The Theater of Terror, Weimann and Winn (1994), advocated that international tourism in a country is significantly affected by terrorists' activities and have make a clear economic impact in the equation between terrorism and tourism. Tourism and terrorism surprisingly have some common characteristic; both tourism and terrorism cross national boarders, both involves communication technologies and travelling, and citizens from different countries are involved in both tourism and terrorism (Sönmez and Graefe (1998); cited in Sönmez, 1998). An adequate number of researchers have argued that terrorism has a negative effect on tourism. Enders and Sandler (1991) for Spain, Bhattacharya and Basu (2010) for India, Feridun (2011) for Turkey, Raza and Jawaid (2013) for Pakistan, Bassil, Hamadeh et al. (2015) for Lebanon and Samitas, Asteriou et al. (2018) for Greece has found negative impact of terrorism on tourism.

Current literature provides several elements of increasing terrorism in both developed and in developing economies. According to Robert (1970) political instability and poverty are some of the main reasons which cause terrorism while Tilly (1978) stated that terrorism increase is due to increasing political violence and opportunism. Similarly, Muller and Seligson (1987) further concluded the work of Gurr (1970) and Tilly (1978) by including income and equity division and found that non-equality of the land causes political instability, which leads to terrorism. Likewise, Muller and Weede (1990) examined that during the oppressed period of government political brutality is at its peak. Similarly, Collier and Hoeffler (2004) reported that mutiny is raised due to lack of opportunities. It is perceived that terrorism activities can lead to heart-breaking life losses and destruction of precious property. Testas and Violence (2004) found the impact of macroeconomic variables on terrorism by gathering different data on Muslim countries. Empirical evidence indicated that there is a negative relationship between education and terrorism. Similarly, a rise in per capita income is related to a decrease in terrorism, while repression is responsible to raise terrorism. Abadie (2006) investigated the effect of terrorism on economic variables and found that economic variables are not the main reason to affect terrorism and suggested that political autonomy is significantly related to terrorism. Moreover, it is revealed that any economy can be affected in three times via the jolts of terrorism Öcal and Yildirim (2010). The direct effect of terrorism is felt in the short-run in the shape of destruction of factors of production. This destruction of factors of production is transitioned to the next level in the shape of less confidence of investors (domestic and foreign) and consumers (international tourists in the case of tourism rich country). Both these factors can lead to a third impact of terrorism on the economy in the long-run as there occur an increase in the cost of transaction because of the related risks and expenditures on counter terrorism which results in the long-run losses in productivity.

In the context of tourism, early literature proved that the global experience of tourists affect their reaction against terrorism and they choose to travel more secure places, thus it is economically disastrous for countries, where terrorism events are increasing day by day (Araña and León 2008; Seddighi, Nuttall et al. 2001; Sönmez and Graefe, 1998; Enders, Sandler et al., 1992); Martin and Gu, 1992; Hartz, 1989; D'Amore and Anuza, 1986; Cook and McCleary, 1983). Moreover, Enders and Sandler (1991) stated that terrorist's attacks are random and autonomous which scares away tourists. While in their another study, Enders, Sandler et al. (1992) found that there is a strong negative impact of terrorism on revenue generated from tourism in Austria, Italy, Greece, and other European countries, although there is no significant impact of terrorism on tourism revenue in Germany, Norway, France, Denmark, and Finland. Similarly, Enders, Sandler et al. (1992); and Sönmez (1998) stated that income from tourism in Italy, Austria, and Greece were degraded by terrorism, therefore, neighboring countries were delicate due to bad negative effect. Additionally, Pizam, \& Smith., (2000) used a quantitative analysis of major global terrorist incidents during the period 1985-98, categorized by date, location, victims, weapons used, severity of damage, motivation, impact on tourism demand, and duration of impact. The study found the impact of these events on the host destination and the global tourism industry. Furthermore, Pizam, \& Fleischer., (2002) study on the impact of terrorist acts on Israel's tourism demand from May 1991 to May 2001 confirmed the following hypothesis: the frequent occurrence of terrorist acts led to a greater decline in the number of international tourist arrivals than terrorist acts.

Gaibulloev and Sandler (2009) analyzed a panel of Asian countries over a period 1970-2004 to quantify the impact of conflicts and terrorist activities on per capita growth. They concluded that international terrorism occurrences can limit the growth of economies. The study further quantified that the per capita growth of nations can be reduced by $1.5 \%$ as a result of an additional attack. Similarly, Alsarayreh, Jawabreh et al. (2010) analyzed the data of 42 different countries and stated that terrorism has a negative impact on tourism, where most respondents believe terrorism has reduced tourism. Additionally, Henderson, Shufen et al. (2010) Examined the effect of terrorism and tourism industry in Singapore and found that terrorism has a negative impact on the destination where it happens. Korstanje, \& Clayton, (2012) explored why tourists continue to visit troubled and often violent countries even with obvious risks. 
He further studied the rise and fall of world travel and tourism demand related to terrorist acts. The results showed that after the 9/11 terrorist attacks in the United States, the number of American tourists in the Caribbean decreased by $13.5 \%$, which resulted in the temporary loss of 365,000 jobs. Similarly, Saha, \& Yap, (2014) used panel data from 1999 to 2009 for 139 countries to analyze the impact of the interaction between political instability and terrorism on the development of tourism. The study measures the extent to which a country's political conflicts and terrorism have a negative impact on tourism. The results show that the impact of political instability on the tourism industry is far more serious than the impact of a one-time terrorist attack.

Moreover, Meierrieks and Gries (2013) analyzed the impact of terrorist activities on the economic growth in a panel of 160 countries over a period 1970 to 2007 and concluded that in the time Cold War, and post-Cold War unstable political condition, low development, active terrorism, and low political openness proved the channels of impact of terrorism towards economic growth. In case of Pakistan, Mehmood (2014) stated that about $33.02 \%$ of its real national income is spent on terrorism i.e. the value of terrorism is about $1 \%$ of actual GDP every year in Pakistan. In a panel study of developed and developing nations over a period 2008-2015. A comprehensive review of the literature and a series of interviews were used by Buultjens, Ratnayake \& Gnanapala., (2016) to examine the impact of the war on the industry and the government's response after the conflict. Despite the rapid increase in the number of international tourists, there are still concerns that government policies may benefit large tourism operators and developers at the expense of small businesses in the informal sector. Lassoued, Hamida et al. (2018) analyzed the relationship between economic growth and terrorism and concluded that there is a positive relationship between terrorism and economic growth both in the case of developed and developing nations. Moreover, the studies that in the case of developing nations economic growth can negatively affect terrorism activities.

Past studies have repeatedly proved that the tourism industry is extremely vulnerable to terrorism and violence, and has shown that tourism is one of the economic sectors most vulnerable to such threats (Avraham, 2015 and Lanouar \& Goaied, 2019). Krajňńk (2020) studied the impact of terrorism on tourism demand. The research aims to contribute to this series of literature by systematically reviewing existing research and then synthesizing its findings. The results concluded that terrorism has a negative impact on tourism demand. Khan et al., (2020) attempts to highlight the role of tourism and terrorism in shaping well-being measures and, to address the mechanism of how tourism and well-being measures can lead to terrorism in developing economies. The study further examines the causal relationship between well-being measures, tourism, terrorism, and inequality by focusing on Pakistan. Hence, the findings suggest significant positive relationships between tourism and well-being measures. The above-said literature focused on different aspects of terrorism and its impact on tourism along with other important variables of interest. There are different factors in the present study like international tourism receipt, overall terrorism, economic growth and terrorism intensity. Thus, this study provides a relatively clear picture of the relationship between terrorism and tourism.

\section{Data and Methodology}

The data used in this paper cover the period from 1980-2016, and its variables are tourism receipts (TR), Overall terrorism (TERR), gross domestic product per capita (CGDP), and terrorism intensity (dummy). The data on tourism receipts and per capita GDP growth is taken from World Development Indicators (WDI) a World Bank data bank and the data on terrorism is taken from the Global Terrorism Database (GTD).

\subsection{Model specification}

The study has focused to evaluate the impact of terrorism on the demand for tourism in South Asian countries. This study extends the work of Raza and Jawaid (2013), where the authors have emphasized only on terrorism incidents to inspect the effect of terrorism on tourism in Pakistan. The current study in addition to terrorism incidents has emphasized on a number of fatalities, number of injuries, and property damage in Pakistan, India and Bangladesh. The focus of this study is the following function to analyze the impact of terrorism on tourism in these countries.

$$
\mathrm{TR}_{\mathrm{t}}=\mathrm{f}\left(\mathrm{Terrt}+\mathrm{CGDP}_{\mathrm{t}}+\text { Dummy }_{\mathrm{t}}\right)
$$

Where TRt is a proxy of tourism receipt at time $t$, Terrt represent Terrorism, CGDPt is a proxy used for GDP per capita and Dummyt is a variable included to measure the terrorism intensity from 2008-2016.

Following the work of Liu et al., (2019), Kumail et al., (2020), Ali et al., (2020) and Ali et al., (2017) the functional relationship in Eq. (1) can be described in logarithmic form to capture the impact of the independent variable (elasticity coefficients) on tourism receipts as follows:

$$
\ln \mathrm{TR}_{\mathrm{t}}=\beta_{0}+\beta_{1} \operatorname{lnTerr}_{\mathrm{t}}+\beta_{2} \operatorname{lnCGDP}_{\mathrm{t}}+\beta_{3} \operatorname{lnDummy}_{\mathrm{t}}+\varepsilon_{\mathrm{t}}
$$

where at period $t, \ln$ TRt is the $\log$ of the number of tourists receipt, $\ln$ Terrt is a log of the variable included to measure the overall terrorism in South Asian countries including Pakistan, India and Bangladesh, lnCGDPt is the log of GDP per capita and $\ln$ Dummyt is the $\log$ to measure the terrorism intensity and $\varepsilon_{\mathrm{t}}$ is the error term. The expected sign of $\beta_{1}$ is negative as most of the previous studies argue that terrorism is deliterious for the tourism industry as people feel reluctant to visit places with a number of terrorism incidents. Furthermore, based on a priori information $\beta_{2}$ may carry a positive sign as economic growth of the country may exert positive influence towards the tourists attraction as the country will spend the adaquate amount of its budget to make the country a tourists heaven. Moreover, the expected sign of $\beta_{3}$ is negative as an increase in the intensity of terrorism activities will repel the international tourists from the destinations with terrorism incidents. 


\subsection{Estimation Technique}

Nexus of

Before to proceed with bounds test approach, we have to fulfill the assumptions of ARDL i.e. variables are stationary of I (0) or I (1) or combination of both. Present authors applied two different unit root test to verify whether the variables are stationary or not i.e. ADF test (Dickey and Fuller 1979), PP-test (Phillips and Perron 1988). ADF test is based on the following equation.

$$
\Delta Y_{t}=Y_{t}=\alpha_{0}+\alpha_{1} Y_{t-1}+\sum_{i=0}^{\pi} d_{j} \Delta Y_{t-1}+\varepsilon_{i}
$$

While PP unit root test can be illustrated algebraically as:

$$
\Delta Y_{t}=\alpha \quad \rho * Y_{t-1} \quad \varepsilon_{i}
$$

The study adopted ARDL bounds technique because it is better than VECM and Johansen test of cointegration due to the following properties. The ARDL method is chosen over other methods because (a) this method uses the OLS approach to estimates the long-run relationship among different variables based on the selection of lag length. (b) It can be applied whether the variables are $\mathrm{I}(0)$ and $\mathrm{I}(1)$ or a mixture of $\mathrm{I}(0)$ and $\mathrm{I}(1)$. (c) It is preferred over Johansen and Juselius method because it is valid for small sample size data. (d) It can combine both long-run and short-run equilibrium by using the error correction mechanism (ECM) by simple linear transformation without disclosing long-run information. (e) This method, it is free from residual correlation and there is no endogeneity problem as the number of lags minimum and maximum are selected automatically under Akaike Information Criterion (AIC) and Schwarz Information Criteria (SIC). (f) It can differentiate the dependent and independent variable. On the contrary, Ouattara (2004) stated that the value of calculated Fstatistics under ARDL bounds test will be invalid for the I(2) variables, therefore, ARDL technique is not applicable in the presence of any second difference stationary variable i.e. I(2) variable. Therefore, the ADF and PP unit root test verified that there is no I(2) variable in the model. The ARDL model designed for estimations is as follows:

$$
\begin{aligned}
& \Delta I n T R_{t}=\alpha=\sum_{i=1}^{n} b_{i} \Delta \ln T R_{t-j}+\sum_{i=0}^{n} c_{i} \Delta \operatorname{In} T e r r_{t-j}+\sum_{i=0}^{n} d_{i} \Delta \ln C G D P_{t-j}+\sum_{i=0}^{n} e_{i} \Delta I n D u m m y_{t-j} \\
& +\sigma_{1} \ln T R_{t-1}+\sigma_{2} \ln T e r r_{t-1}+\sigma_{3} \ln C G D P_{t-1}+\mu_{t}
\end{aligned}
$$

Where $\alpha^{\circ}$ is a constant term and $\mu_{\mathrm{t}}$ is error term, where summation sign represents the error correction dynamic and the remaining part of the equation carrying $\sigma$ which represents the long-term relationship. According to the Pesaran and Pesaran (1997) if the F-statistics value is smaller than lower bound value than there will be no long-run relationship between variables, while if the values of F-statistics is in between the critical values than the test will be indecisive. This method can also choose the best possible lag length for smallest using Schwartz-Bayesian Criteria (SBC), and for the maximum lag length of the variables by using Akaike information Criteria (AIC). Similarly, if there is a long-run connection between tourism and terrorism, then we evaluate the long-run coefficients by using the following model:

$$
\ln T R_{t}=\sigma_{0}+\sigma_{1} \ln T e r_{t-j}+\sigma_{2} \ln C G D P_{t-j}+\sigma_{3}+\mu_{t}
$$

Furthermore, the following model is to estimate the short-run coefficient.

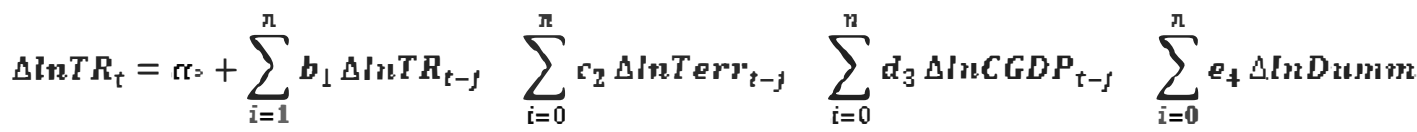

$$
\begin{aligned}
& n E C T_{t-j}+\mu_{t}
\end{aligned}
$$


The error correction term $\mathrm{ECT}_{(\mathrm{t}-\mathrm{j})}$ shows the pace of adjustment towards the long-term equilibrium if there is any disequilibrium resulted from the short-run shock. Similarly, in the model coefficient of error correction term is denoted by $\mathrm{n}$ which shows the speed of adjustment.

\section{Empirical results}

First, this study investigated the descriptive statistics to find out the different properties of the variables. The descriptive statistics table shows that a series of tourism receipt, terrorism, and economic growth are normally distributed shown by Jarque-Bera statistic. Table 2 shows the descriptive statistics of variables.

The present study used ADF and PP unit root tests to check the variables whether they are stationary at the level I(0) or first difference I(1). Similarly, the results of ADF and PP shows that all variables are stationary at first difference I(1) which indicates that there is a valid long-run connection between tourism receipt, terrorism, and CGDP. Table 3 shows the result of ADF and PP unit root tests.

Based on the results of ADF and PP unit root test, all variables at first difference are stationary. Therefore, to analyze the long-run relationship between variables we can apply both ARDL and Johansen cointegration tests. Hence, instead of the Johansen cointegration test, the current study preferred the ARDL bound test to check the small sample properties.

Table 2: Descriptive statistics

\begin{tabular}{lcccccccccc} 
& \multicolumn{3}{c}{ Pakistan } & \multicolumn{3}{c}{ India } & \multicolumn{3}{c}{ Bangladesh } \\
& LNTR & LNTERR & LNCGDP & LNTR & LNTERR & LNCGDP & LNTR & LNTERR & LNCGDP \\
Mean & 13.15 & 6.97 & 8.16 & 22.74 & 5.39 & 6.94 & 17.81 & 3.192 & 6.45 \\
Maximum & 13.96 & 9.64 & 8.56 & 23.86 & 6.93 & 7.52 & 18.98 & 6.15 & 6.93 \\
Minimum & 12.57 & 1.87 & 7.72 & 21.67 & 4.11 & 6.43 & 14.00 & 0.69 & 6.03 \\
Std. dev. & 0.36 & 1.94 & 0.22 & 0.80 & 0.81 & 0.34 & 1.17 & 1.31 & 0.27 \\
Jargue-Bera & 2.81 & 3.98 & 1.11 & 2.37 & 1.45 & 1.67 & $\mathbf{3 4 . 4 7}$ & 0.59 & 1.36
\end{tabular}

Table:3 Unit rootteru

\begin{tabular}{|c|c|c|c|c|}
\hline \multirow{2}{*}{\multicolumn{2}{|c|}{ Variables }} & \multicolumn{2}{|c|}{ ADF } & \multirow[b]{2}{*}{$\lfloor(10)$} \\
\hline & & $\underline{1101}$ & 니 & \\
\hline & LNTR & -1.337 & $-4.982^{\neq \neq \neq}$ & -1.025 \\
\hline \multirow[t]{3}{*}{ Pakistan } & LNTERR & -1.805 & $-6.633^{* * *}$ & -1.635 \\
\hline & LNCGDP & -0.637 & $-3.889 * * \neq$ & -1.295 \\
\hline & LNTR & -0.218789 & $-3.527913^{* *}$ & -0.237724 \\
\hline \multirow[t]{3}{*}{ India } & LNTERR & -1.56442 & $-5.98956^{* * *}$ & -1.33723 \\
\hline & LNCGDP & 1.519459 & $-3.4837^{* \neq}$ & 1.548749 \\
\hline & LNTR & $-2.92716^{* *}$ & $6.10077^{* \neq *}$ & $-3.11955^{\neq *}$ \\
\hline \multirow[t]{2}{*}{ Bangladesh } & LNTERR & -2.12142 & $-5.98644^{* * *}$ & -2.14618 \\
\hline & LNCGDP & -1.41442 & $-3.94791^{\neq *}$ & -2.42228 \\
\hline
\end{tabular}

Note: ${ }^{*}, * * \& * \neq *$ refers te rejection of null hypothesis that unit ro texists at $10 \%, 5 \% \& 1 \%$

respectively.
PP

$$
\begin{aligned}
& \text { 니) } \\
& -3.669 * * \neq \\
& -7.375^{* * *} \\
& \text {-3. } 891^{* * \neq} \\
& -3.428414^{* *} \\
& -7.11625 * \neq \\
& -3.49661^{* *} \\
& -6.10077^{* \neq *} \\
& -4.14754 * \neq * \\
& \text { B. } 11068^{* \neq *}
\end{aligned}
$$

\begin{tabular}{|c|c|c|c|c|c|}
\hline & \multirow[t]{2}{*}{ Variables } & \multicolumn{2}{|c|}{ ADF } & \multicolumn{2}{|c|}{$\mathbf{P P}$} \\
\hline & & $\underline{110 !}$ & $\underline{\underline{41\}}}$ & 니니 & 니 \\
\hline & LNTR & -1.337 & $-4.982^{* * \neq}$ & -1.025 & $-3.669^{* * \neq}$ \\
\hline \multirow[t]{3}{*}{ Pakistan } & LNTERR & -1.805 & $-6.633^{* * \neq}$ & -1.635 & $-7.375^{* * \neq}$ \\
\hline & LNCGDP & -0.637 & $-3.889 * * \neq$ & -1.295 & $-3.891^{* * \neq}$ \\
\hline & LNTR & -0.218789 & $-3.527913^{* *}$ & -0.237724 & $-3.428414^{\neq *}$ \\
\hline \multirow[t]{3}{*}{ India } & LNTERR & -1.56442 & $-5.98956 * * \neq$ & -1.33723 & $-7.11625^{* \neq *}$ \\
\hline & LNCGDP & 1.519459 & $-3.4837^{* \neq}$ & 1.548749 & $-3.49661^{* *}$ \\
\hline & LNTR & $-2.92716^{* *}$ & $6.10077^{* \neq *}$ & $-3.11955^{\neq *}$ & $-6.10077^{* \neq *}$ \\
\hline \multirow[t]{2}{*}{ Bangladesh } & LNTERR & -2.12142 & $-5.98644^{* * *}$ & -2.14618 & $-4.14754^{* \neq *}$ \\
\hline & LNCGDP & -1.41442 & $-3.94791^{* *}$ & -2.42228 & $-8.11068^{* \neq *}$ \\
\hline
\end{tabular}

Johansen cointegration tests. Hence, instead of the Johansen cointegration test, the current study preferred the ARDL bound test to check the small sample properties.

Table:3 Unit root tests

Table 4 described the results of ARDL bound tests for Pakistan, India and Bangladesh in detail. The computed F-statistics of Pakistan is 6.649 which are greater than both the lower bound value of 5.17 and the upper bound value of 6.36 at level 1\%. Similarly, the F-statistics of India is 5.29 which are greater than both the lower bound value of 3.23 and the upper bound value of 4.35 at level $5 \%$. Last but not the least, the calculated F-statistics value of Bangladesh is 4.14 which are greater than both the lower bound value of 2.72 and the upper bound value of 3.77 at level $10 \%$.

(Pesaran, Shin et al. 2001) and (Narayan 2005) developed critical bounds values which are appropriate for testing small sample size data. The bound test analysis indicated that there is a significant long-run relationship between tourism receipts, terrorism and economic growth. 
Table 4: ARDL Bounds Test Cointegration

Nexus of

\begin{tabular}{lccccccc}
\hline \multicolumn{2}{l}{ Variables: LNTR (LNTERR, LNCGDP, Dummy) } & \multicolumn{2}{c}{ Critical Values } \\
\hline Country & F-statistic & \multicolumn{2}{c}{ Pakistan } & \multicolumn{2}{c}{ India } & \multicolumn{2}{c}{ Bangladesh } \\
& & I(O) & I(1) & I(0) & I(1) & I(0) & I(1) \\
\hline Pakistan & $6.649^{* * *}$ & 3.47 & 4.45 & 2.72 & 3.77 & 2.72 & 3.77 \\
\hline India & $5.2959^{* *}$ & 4.01 & 5.07 & 3.23 & 4.35 & 3.23 & 4.35 \\
\hline Bangladesh & $4.1484^{*}$ & 5.17 & 6.36 & 4.29 & 5.61 & 4.29 & 5.61 \\
\hline \multicolumn{7}{l}{ Remarks: Cointegration } \\
\hline \multicolumn{7}{l}{ Note: *, **, *** indicates cointegration at 10\%, 5\% and 1\%. }
\end{tabular}

\subsection{The ARDL long-run and short-run results}

Table 5 shows the results of the ARDL long-run estimation. The results indicate a negative yet statistically significant impact of terrorism on tourism which is in accordance with the first research hypothesis for Pakistan, India and Bangladesh. All of the other results are also in line with the set hypotheses. The GDP per capita in tourism have positive and highly significant coefficient for Pakistan and India. For the said countries of South Asia i.e. Pakistan, India and Bangladesh, all of the variables have the expected sign. The main variable of interest is terrorism; however, it is negatively significant. According to the research results, a $1 \%$ increase in terrorism will lead to a decrease in the tourism receipt by $0.26 \%$ in Pakistan but for India and Bangladesh this percentage is $0.32 \%$ and $0.37 \%$. The results of our current study are in line with current empirical studies, for example, Raza and Jawaid (2013), Samitas, Asteriou et al. (2018).

Table 5: ARDL Estimation and Long-run Coefficients

\begin{tabular}{lcccc}
\hline \multirow{2}{*}{ Pep. Variable } & LNTERR & \multicolumn{2}{c}{ LNCGDP } & \multirow{2}{*}{ CONSTANT } \\
\cline { 3 - 5 } & \multirow{2}{*}{ LNTR } & -0.259 & 5.409 & -28.49 \\
& & $(-2.598)^{* * *}$ & $(2.486)^{* * *}$ & $(-1.699)$ \\
\hline \multirow{2}{*}{ India } & \multirow{2}{*}{ LNTR } & -0.323 & 2.841 & 4.604 \\
& & $(-3.741)^{* * *}$ & $(17.177)^{* * *}$ & $(6.221)^{* * *}$ \\
\hline \multirow{2}{*}{ Bangladesh } & \multirow{2}{*}{ LNTR } & -0.372 & 4.834 & -10.507 \\
& & $(-2.647)^{* *}$ & $(5.686)^{* * *}$ & $(-2.137)^{* *}$ \\
\hline
\end{tabular}

Note: () showings t-statistic values for ARDL and probability value for diagnostic test, ${ }^{*}, * *$ $\&^{* * *}$ refers level of significance at $10 \%, 5 \% \& 1 \%$ respectively

As far as the other variables are concerned, a 1\% increase in the lagged value of GDP in international tourism receipt leads to an increase of 5.4\% in the GDP per capita in tourism inflow for Pakistan but for India it is $2.8 \%$ and 4.8 for Bangladesh. The results of the current study are consistent with the work of Balaguer and Cantavella-Jorda (2002), Katircioglu (2009) and Kreishan (2011), Adnan Hye and Ali Khan (2013), Jalil, Mahmood et al. (2013). Similarly, the study further investigated the impact of an increase in the terrorist activities (terrorism intensity) on the tourism receipts and found that increase in terrorism intensity has a negative impact on the tourism receipts. The results for Pakistan shows that if the intensity of terrorism increases by $1 \%$ it will lead to a further reduction of $0.27 \%$ in the tourism receipts. This result states that terrorism activities may lead to decrease the tourism receipts by $0.26 \%$, but a period where there is an increase in the intensity of terrorism activities there occur a further decrease of $0.27 \%$ in the tourism receipts. Furthermore, the result of India shows that if the terrorism intensity is increased by $1 \%$ will also lead to decrease $0.17 \%$ in the international tourist's receipt. Moreover, as compared to Pakistan and India, in Bangladesh if the intensity of terrorism is increase by $1 \%$ it will lead to decline $0.39 \%$ in tourist receipts. Thus, it is claimed that terrorism is one of the main obstacles in the way of development of tourism in Pakistan, India and Bangladesh. This outcome may be is justified in the case of Pakistan, India and Bangladesh international tourists' receipts has decreased over the years when the intensity of terrorism has increased during the last and recent decade.

The study under the ARDL model further emphasized on the short-run estimates of the coefficients, the error correction term ECM (-1) is statistically strong and negative which is necessary for the ARDL model to be valid. The ECM assessment tells that the disequilibrium in tourism receipts, made by the independent variables in the short-run will be adjusted back to equilibrium with a $49 \%$ in the long run and speed of adjustment in one year for Pakistan. The ECM results are shown in Table 6 below. In short-run, $1 \%$ rise in terrorist activities will lead to a decrease in the tourists' receipts by $0.06 \%$. Similarly, in case of India, $1 \%$ increase in terrorism will lead to decrease in the international tourist's receipts by $0.16 \%$ while for Bangladesh these tourist's receipts in decline by $0.37 \%$. While on the other hand, any improvements in the economic growth of a country will be reflected as an increase of $2.7 \%$ in the tourists' receipts which is encouraging in the case of Pakistan, but for India this increase in GDP per capita is $4.8 \%$ in the international tourist's receipts while there is a negative but significant relationship between GDP per capita and tourism in Bangladesh. Surprisingly, the dummy variable, which shows the intensity of terrorism in short-run, is having a negative but insignificant impact on the tourists' receipts in Pakistan, India and Bangladesh. This outcome states that terrorism intensity will show its repercussions in the long-run as they have a strong negative impact on the tourists' receipts, but have no such significant role in determining the tourists' receipts in these countries. 
Table: 6 Error Correction Model (ECM)

\begin{tabular}{|c|c|c|c|c|c|}
\hline & Dep. Variable & $\Delta$ LNTERR & $\Delta$ LNCGDP & $\triangle$ DUMMY & ECM(-1) \\
\hline Pakistan & TR & $\begin{array}{c}-0.066 \\
(-2.109)^{* *}\end{array}$ & $\begin{array}{c}2.686 \\
(2.787)^{* *}\end{array}$ & $\begin{array}{c}-0.202 \\
(-1.013)\end{array}$ & $\begin{array}{c}(-0.496) \\
(-3.911)^{*}\end{array}$ \\
\hline India & TR & $\begin{array}{l}-0.164039 \\
(-3.247)^{* *}\end{array}$ & $\begin{array}{c}4.809958 \\
(4.013)^{* * *}\end{array}$ & $\begin{array}{c}-0.019234 \\
(-0.236)\end{array}$ & $\begin{array}{c}-0.852562 \\
(-4.180)^{* * *}\end{array}$ \\
\hline Bangladesh & TR & $\begin{array}{l}-0.373352 \\
(-2.320)^{* *}\end{array}$ & $\begin{array}{c}-34.593504 \\
(-1.704)\end{array}$ & $\begin{array}{c}-0.395726 \\
(-0.888) \\
\end{array}$ & $\begin{array}{c}-0.881039 \\
(-5.157)^{* * *}\end{array}$ \\
\hline
\end{tabular}

Note :() Shows t-statistic, ${ }^{*}, * * \& * * *$ shows level of significance at $10 \%, 5 \% \& 1 \%$ respectively.

This study further applied numerous diagnostic tests to show several indications of a violation of the assumptions of the classical linear regression model. This study applied Breusch-Godfrey LM test and reliably disclose that the residuals are not serially correlated. The study investigated the presence of heteroscedasticity in the model and concluded that residuals are homoscedastic and there is no problem of heteroscedasticity in the model. Similarly, Jarque-Bera (J-B) normality test null hypothesis cannot be rejected, which suggests that the prediction residuals are usually circulated. Therefore, the standard statistical implications t-statistic, F-statistic and R-squares are valid. The functional form of the model is well identified stated by Ramsey RESET test and there is no chance of missing nonlinear relationship in terms of squares or cubes. The empirical result seems to be very worthy in terms of normal diagnostic statistics. The value of R-squared for Pakistan $0.62 \%, 0.83 \%$ for India and $0.60 \%$ for Bangladesh and shows dissimilarity in the dependent variable which is described by independent variables. The F-statistics value is greater than its critical value suggesting the fit and overall impact of the expected model. Hence, empirically the suitability of the model is acceptable. The results of diagnostic tests are shown in Table 7.

\begin{tabular}{lcccccc}
\multicolumn{6}{l}{ Table: 7 Diagnostic Tests Results } \\
\cline { 2 - 7 } & $\mathbf{R}^{2}$ & Heteroscedasticity & $\begin{array}{c}\text { Adjusted } \\
\mathbf{R}^{2}\end{array}$ & Jarque-Bera & $\begin{array}{c}\text { Serial } \\
\text { Correlation }\end{array}$ & F-stat (Prob.) \\
\cline { 2 - 7 } Pakistan & 0.623 & $0.601(0.85)$ & 0.574 & $0.020(0.98)$ & $0.045(0.07)$ & $3.111(0.017)$ \\
\hline India & 0.836 & $0.763(0.99)$ & 0.579 & $1.517(0.468)$ & $6.052(0.053)$ & $3.252(0.044)$ \\
\hline Bangladesh & 0.601 & $11.854(0.05)$ & 0.468 & $1.324(0.51)$ & $0.53(0.44)$ & $4.520(0.010)$ \\
\hline
\end{tabular}

Fig.1, Fig.2 and Fig.3, represent the CUSUM and CUSUMsq graphs of Pakistan, India and Bangladesh. Both the tests identify that CUSUM and CUSUMsq are fallen in the critical boundaries at $5 \%$ level of significance. This means that the accuracy of long-run and short-run parameters which influence tourism in Pakistan. Therefore, these tests also verify the stability of the ARDL model for structural stability and it is found that there is no structural break.

Figure 1: Graph of CUSUM and CUSUMSQ Test of Pakistan

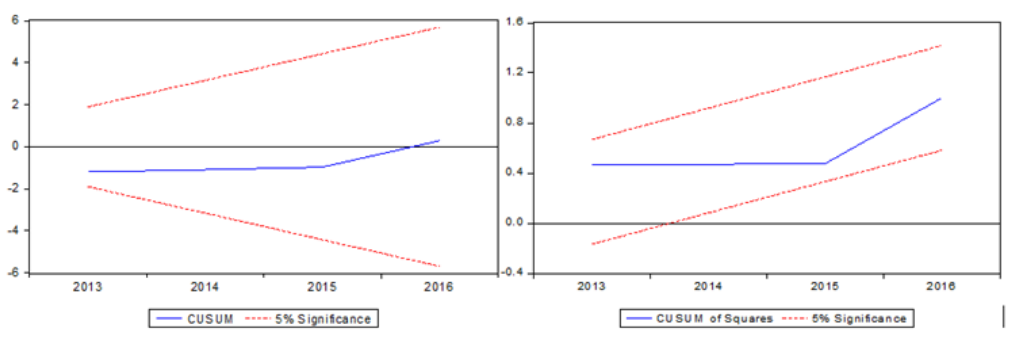

Figure 2: Graph of CUSUM and CUSUMSQ Test of India

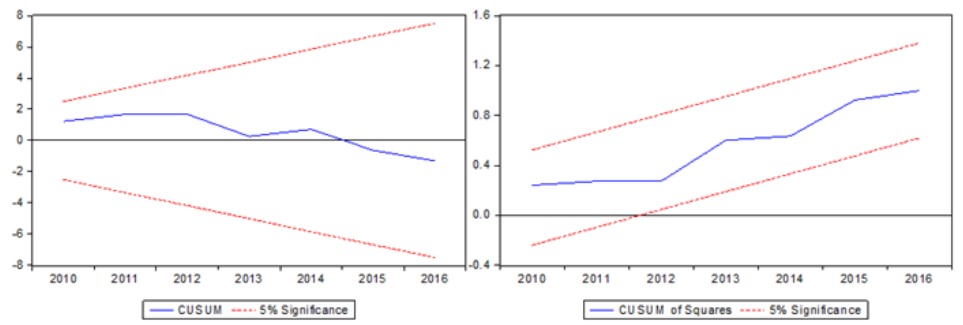




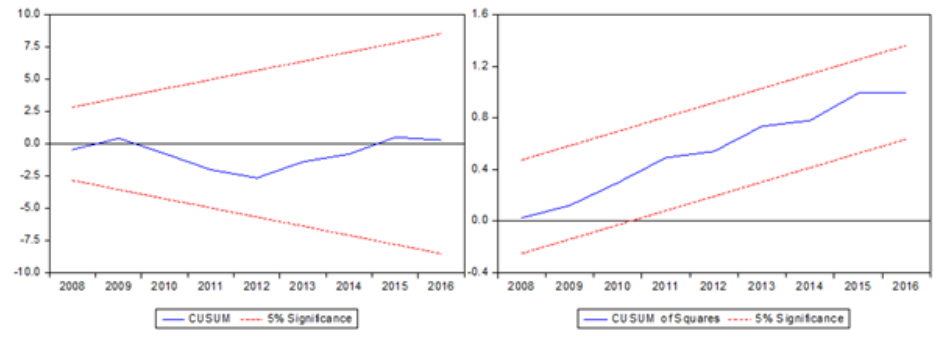

\subsection{Granger causality results}

This study found that there is a long-run relationship between tourism and terrorism in Pakistan, India and Bangladesh. Moreover, the direction of causality is not clear from the ARDL cointegration test. Therefore, we conduct a Granger causality test to expose the direction of causality. It is clear from Table 8 that the null hypothesis of terrorism does not Granger cause tourism and is clearly rejected at $5 \%$ in these countries. These outcomes reveal that terrorist activities in Pakistan, India and Bangladesh are one of the main reasons that cause a decrease in the tourist receipts in the country. Similarly, the null hypothesis of GDP does not Granger cause tourism and is rejected at 5\% which conclude that GDP can cause tourists' receipts in these three countries. The null hypothesis of GDP does not Granger cause terrorism and is rejected at $1 \%$ in Pakistan, India and Bangladesh which means that if the country's economic growth increases it can have some positive role in decreasing terrorism as there will be more employment opportunities and people will not be an easy prey for terrorist organizations to involve them in terrorist activities. Thus, we can say that terrorism activities can be the sole cause of the decrease in international tourists' receipts in Pakistan, India and Bangladesh.

Table 8: Granger Causality Tests

Variables:

LNTER does not Granger Cause LNTR

LNCGDP does not Granger Cause LNTR

\begin{tabular}{cc}
\multicolumn{2}{c}{ Pakistan } \\
F-Stat & Preb. \\
$3.70 \mathrm{~g}$ & $0.036^{\neq *}$ \\
4.156 & $0.025^{\neq *}$ \\
$5.39 \mathrm{~g}$ & $0.009^{* \neq *}$
\end{tabular}

India

F-Stat

Prob.

3.754

4.907

$0.047^{* *}$

$0.022^{\neq *}$

$5.684 \quad 0.014^{\neq *}$
F-Stat
6.07132
33.6526
6.35415

Bangladesh

$0.0117^{* *}$

$0.0000^{\neq * *}$

$0.01 * *$

\section{Conclusion}

This study examines the relationship between terrorism and tourism from in Pakistan, India and Bangladesh by analyzing secondary data over the period 1980-2016. The study utilized the ARDL approach to explore the short and long-run relationship between the study variables. Results show the significant negative impact of terrorism on tourism in the long-run as well as in short-run. The findings of our study are compatible with the current literature including Raza and Jawaid (2013); Samitas, Asteriou et al. (2018) and Buigut (2018) and suggest that the government should focus on the problem of terrorism to cope with the low international tourism receipts. The results concluded that during the study period there occur a decrease in growth of the overall tourists' receipts because of the increase in terrorist activities. The study, thus, concluded that because of terrorism activities international tourists visit alternative places rather than the terrorism-hit tourism spots, thus, there occurs a decrease in the tourists' receipts. The study suggests that the government should emphasize boosting the tourism receipts by investing in counter terrorism activities and promoting the tourism industry by ensuring fool proof security to increase the tourist's confidence to visit tourism points in these countries. The study also concluded that an increase in the economic growth could lead to an increase in the investments of the government and private sector in the tourism development in terms of infrastructure including roads, buildings, and hotels, and also in terms of making the country peaceful and attractive for international tourists, which will increase the tourists receipts in the country. Moreover, the study concluded that an increase in the intensity of terrorism has caused a decrease in the tourism receipts more than the period where the intensity was not that much severe. Thus, the study suggests that government and security agencies must act promptly to reduce the intensity of terrorism to decrease the loss to the economy in terms of decrease in the tourism receipts. The media of the country should also play its role by advertising to improve the confidence of international tourists to visit the tourist spots in the country.

Results of Granger causality supports the long-run impact of terrorism on tourists receipts as an increase in terrorism can cause a decrease in tourist receipts. On the other hand, Granger causality results conclude that economic growth could be a cause for boosting the tourism industry, which in turn can attract more international tourists. The results further conclude that an intensity of terrorism could be harmful towards tourism development, as an increase in terrorist activities will repel international tourists from visiting places in Pakistan, India and Bangladesh. Last, by not the least, this study confirms a unidirectional causality from CGDP towards tourism which means that increase in economic growth of the country could support the tourism industry, thus, can attract more international tourists. 
In the perspective of policy implementation, the government of Pakistan, India and Bangladesh must take quick actions to control terrorism since it is destructive to the tourism industry as well as in light of its negative effect on economic development of a country. Moreover, the government should expand the business and employment opportunities not just in light of the fact that unemployment is harmful to economic growth yet additionally to spare the economy from terrorism as unemployed people can easily become the puppets of terrorist groups by paying them and to feed their families. This study is helpful to policy maker and future researcher as this study provides the complete picture of terrorism in terms of the index to cover the number of incidents, number of fatalities, numbers of injuries, and property damage.

\section{References}

Abadie, A. (2006). Poverty, political freedom, and the roots of terrorism. American Economic Review, 96(2), 50-56.

Adnan Hye, Q. M., and Ali Khan, R. E. (2013). Tourism-led growth hypothesis: A case study of Pakistan. Asia Pacific Journal of Tourism Research, 18(4), 303-313.

Alia, W., Sadiqb, F., Kumail, T., and Aburumman, A. A. (2020). Do International Tourism, Structural Changes, Trade Openness and Economic Growth Matter in determining CO2 emissions in Pakistan?. Tourism Analysis, 25(2-3), 2-3.

Alsarayreh, M. N., Jawabreh, O. A., and Helalat, M. S. (2010). The influence of terrorism on the international tourism activities. European journal of social sciences, 13(1), 145-160.

Arana, J. E., and León, C. J. (2008). The impact of terrorism on tourism demand. Annals of tourism research, 35(2), $299-315$.

Avraham, E. (2015). Destination image repair during crisis: Attracting tourism during the Arab Spring uprisings. Tourism Management, 47, 224-232.

Baker, D. (2014). The effects of terrorism on the travel and tourism industry. The international journal of religious tourism and pilgrimage, 2(1), 58-67.

Balaguer, J., and Cantavella-Jorda, M. (2002). Tourism as a long-run economic growth factor: the Spanish case. Applied economics, 34(7), 877-884.

Bassil, C., Hamadeh, M., and Samara, N. (2015). The tourism led growth hypothesis: the Lebanese case. Tourism Review.

Bhattacharya, M., and Basu, K. (2010). Impact of terror incidents on the foreign tourist arrivals in India: An econometric exploration. International Journal of Tourism Policy, 3(3), 213-222.

Buigut, S. (2018). Effect of terrorism on demand for tourism in Kenya: A comparative analysis. Tourism and Hospitality Research, $18(1), 28-37$.

Buultjens, J. W., Ratnayake, I., and Gnanapala, W. A. C. (2016). Post-Conflict tourism development in Sri Lanka: implications for building resilience. Current Issues in Tourism, 19(4), 355-372.

Chen, R. J., and Noriega, P. (2004). The impacts of terrorism: Perceptions of faculty and students on safety and security in tourism. Journal of Travel \& Tourism Marketing, 15(2-3), 81-97.

Cohen, E., and Cohen, S. A. (2012). Current sociological theories and issues in tourism. Annals of Tourism Research, 39(4), 2177-2202.

Collier, P., and Hoeffler, A. (2004). Greed and grievance in civil war. Oxford economic papers, 56(4), 563-595.

Cook, R. L., and McCleary, K. W. (1983). Redefining vacation distances in consumer minds. Journal of Travel Research, 22(2), 31-34.

D'Amore, L. J., and Anuza, T. E. (1986). International terrorism: Implications and challenge for global tourism. Business Quarterly, 4(November), 20-29.

Dickey, D. A., and Fuller, W. A. (1979). Distribution of the estimators for autoregressive time series with a unit root. Journal of the American statistical association, 74(366a), 427-431.

Enders, W., and Sandler, T. (1991). Causality between transnational terrorism and tourism: The case of Spain. Studies in Conflict \& Terrorism, 14(1), 49-58.

Enders, W., Sandler, T., and Parise, G. F. (1992). An econometric analysis of the impact of terrorism on tourism. Kyklos, 45(4), 531-554.

Feridun, M. (2011). Impact of terrorism on tourism in Turkey: empirical evidence from Turkey. Applied Economics, 43(24), 3349-3354.

Floyd, M. F., Gibson, H., Pennington-Gray, L., and Thapa, B. (2004). The effect of risk perceptions on intentions to travel in the aftermath of September 11, 2001. Journal of Travel \& Tourism Marketing, 15(2-3), 19-38.

Gaibulloev, K., and Sandler, T. (2009). The impact of terrorism and conflicts on growth in Asia. Economics \& Politics, 21(3), 359-383.

Gunduz*, L., and Hatemi-J, A. (2005). Is the tourism-led growth hypothesis valid for Turkey?. Applied Economics Letters, 12(8), 499-504.

Hartz, C. (1989). Business executives as international terrorist targets. International Terrorism: The Decade Ahead, 21-28.

Henderson, J. C., Shufen, C., Huifen, L., and Xiang, L. L. (2010). Tourism and terrorism: A hotel industry perspective. Journal of Tourism, Hospitality \& Culinary Arts (JTHCA), 2(1), 1-14.

Hye, Q. M. A. (2012). Long term effect of trade openness on economic growth in case of Pakistan. Quality \& Quantity, 46(4), 1137 1149 .

Isaac, R. K., and Velden, V. (2018). The German source market perceptions: how risky is Turkey to travel to?. International Journal of Tourism Cities. 
Jalil, A., Mahmood, T., and Idrees, M. (2013). Tourism-growth nexus in Pakistan: Evidence from ARDL bounds tests. Economic Modelling, 35, 185-191.

Katircioglu, S. T. (2009). Revisiting the tourism-led-growth hypothesis for Turkey using the bounds test and Johansen approach for cointegration. Tourism Management, 30(1), 17-20.

Nexus of

Terrorism and Tourism

Khan, A., Bibi, S., Lyu, J., Raza, A., Hayat, H., and Meo, M. S. (2020). Unraveling the Nexuses of Tourism, Terrorism, and Well-Being: Evidence from Pakistan. Joumal of Hospitality \& Tourism Research, 1096348020917742.

Kingsbury, P. T., and Brunn, S. D. (2004). Freud, tourism, and terror: Traversing the fantasies of post-September 11 travel magazines. Joumal of Travel and Tourism Marketing, 15(2-3), 39-61.

Korstanje, M. E., and Clayton, A. (2012). Tourism and terrorism: conflicts and commonalities. Worldwide Hospitality and Tourism Themes. 4(1): 8-25

Krajňák, T. (2020). The effects of terrorism on tourism demand: A systematic review. Tourism Economics, 1354816620938900.

Kreishan, F. M. (2011). Time-series evidence for tourism-led growth hypothesis: A case study of Jordan. International Management Review, 7(1), 89.

Kumail, T., Ali, W., Sadiq, F., Wu, D., and Aburumman, A. (2020). Dynamic linkages between tourism, technology and CO2 emissions in Pakistan. Anatolia, 1-13.

Lanouar, C., and Goaied, M. (2019). Tourism, terrorism and political violence in Tunisia: Evidence from Markov-switching models. Tourism Management, 70, 404-418.

Lassoued, T., Hamida, A., and Hadhek, Z. (2018). Terrorism and Economic Growth. International Journal of Economics and Financial Issues, 8(1), 175.

Liu, Y., Kumail, T., Ali, W., and Sadiq, F. (2019). The dynamic relationship between CO2 emission, international tourism and energy consumption in Pakistan: a cointegration approach. Tourism Review.

Martin, T. L., and Gu, Z. (1992). Terrorism, seasonality, and international air tourist arrivals in central Florida: an empirical analysis. Joumal of Travel \& Tourism Marketing, 1(1), 3-17.

Mehmood, S. (2014). Terrorism and the macroeconomy: Evidence from Pakistan. Defence and Peace Economics, 25(5), 509-534.

Meierrieks, D., and Gries, T. (2013). Causality between terrorism and economic growth. Joumal of Peace Research, 50(1), 91-104.

Muller, E. N., and Seligson, M. A. (1987). Inequality and insurgency. The American Political Science Review, $425-451$.

Muller, E. N., \& Weede, E. (1990). Cross-national variation in political violence: A rational action approach. Joumal of conflict resolution, 34(4), 624-651.

Narayan, P. K. (2005). The saving and investment nexus for China: evidence from cointegration tests. Applied economics, 37(17), 1979-1990.

Öcal, N., and Yildirim, J. (2010). Regional effects of terrorism on economic growth in Turkey: A geographically weighted regression approach. Joumal of Peace Research, 47(4), 477-489.

Ouattara, B. (2004). Modelling the long run determinants of private investment in Senegal (No. 04/05). Credit Research Paper.

Pesaran, M. H., and Pesaran, B. (1997). Working with Microfit 4.0: interactive econometric analysis;[Windows version]. Oxford University Press.

Pesaran, M. H., Shin, Y., and Smith, R. J. (2001). Bounds testing approaches to the analysis of level relationships. Journal of applied econometrics, 16(3), 289-326.

Perron, P. (1990). Testing for a unit root in a time series with a changing mean. Journal of Business \& Economic Statistics, 8(2), 153-162.

Pizam, A., and Fleischer, A. (2002). Severity versus frequency of acts of terrorism: Which has a larger impact on tourism demand?. Joumal of Travel research, 40(3), 337-339.

Pizam, A., and Smith, G. (2000). Tourism and terrorism: A quantitative analysis of major terrorist acts and their impact on tourism destinations. Tourism Economics, 6(2), 123-138.

Raza, S. A., and Jawaid, S. T. (2013). Terrorism and tourism: A conjunction and ramification in Pakistan. Economic Modelling, $33,65-70$.

Richter, L. K., and Waugh Jr, W. L. (1986). Terrorism and tourism as logical companions. Tourism management, 7(4), $230-238$.

Risso, W. A., Barquet, A., and Brida, J. G. (2010). Causality between economic growth and tourism expansion: empirical evidence from Trentino-Alto Adige. Tourismos: an international multidisciplinary joumal of tourism, 5(2), 87-98.

Robert, G. T. (1970). Why men rebel.

Saha, S., and Yap, G. (2014). The moderation effects of political instability and terrorism on tourism development: A crosscountry panel analysis. Joumal of Travel Research, 53(4), 509-521.

Samitas, A., Asteriou, D., Polyzos, S., and Kenourgios, D. (2018). Terrorist incidents and tourism demand: Evidence from Greece. Tourism management perspectives, 25, 23-28.

Seddighi, H. R., Nuttall, M. W., and Theocharous, A. L. (2001). Does cultural background of tourists influence the destination choice? An empirical study with special reference to political instability. Tourism management, 22(2), 181-191.

Sönmez, S. F., and Graefe, A. R. (1998). Influence of terrorism risk on foreign tourism decisions. Annals of tourism research, 25(1), 112-144.

Sönmez, S. F. (1998). Tourism, terrorism, and political instability. Annals of tourism research, 25(2), 416-456.

Testas, A. (2004). Determinants of terrorism in the Muslim world: An empirical cross-sectional analysis. Terrorism and Political Violence, 16(2), 253-273 
Veréb, V. N., Nobre, H., and Farhangmehr, M. (2018). The fear of terrorism and shift in cosmopolitan values. International Journal of Tourism Cities.

Weimann, G., and Winn, C. (1994). The theater of terror: Mass media and international terrorism (pp. 17-50). New York: Longman. World Tourism Organization (2018). Tourism highlights. Madrid: World Tourism Organization. 